\title{
A COMPARISON OF PERCEPTIONS AND ADAPTED BEHAVIORS BETWEEN EMPLOYEES AND ENTREPRENEURS AGAINST PANDEMIC COVID-19 PANDEMIC
}

\author{
M. Azka Kesuma Wardana*), Eko Ruddy Cahyadi*), and Alim Setiawan Slamet*) \\ ${ }^{*}$ Departement of Management Faculty of Economics and Management, IPB University \\ Jl. Agatis, Campus IPB Dramaga Bogor 16680, Indonesia
}

\begin{abstract}
New normal is a change in behavior to continue carrying out normal activities and implementing health protocols to prevent Covid-19 transmission. After the implementation of the new normal, it automatically affects the routine activities carried out by the community, especially those activities which are limited by the government when New Normal is implemented. This study analyzes perceptions and adaptive behavior between employees and entrepreneurs when implementing New Normal during the Covid-19 pandemic. The approach used is a modified Theory of Planned Behavior (TPB). A total of 427 respondents who is an employee have answered the online questionnaire containing 61 questions. In this research, after the respondents' characteristics were classified, the descriptive analysis carried out with a standard deviation approach, mean value and an independent sample T-test were done using the SPSS 25 software. Insignificance was found in indicators of vulnerability and understanding of Covid-19. Significant differences between employees and entrepreneurs were found in the attitude indicators of Covid-19, which are easy to spread, the number of cases died, the influence of friends, the ability to have internet quotas, past work behavior, past handwashing behavior, The perceived severity is related to medical costs if exposed to Covid-19 and reduced income due to the severity of Covid-19. Perceptions between employees and entrepreneurs have significant differences on several indicators. These differences arise because of their environment, both the work environment and the environment around where they live.
\end{abstract}

Keywords: Covid-19, adapted behavior, new normal, the theory of planned behavior, employee, entrepreneur

\begin{abstract}
Abstrak: New normal adalah perubahan perilaku untuk tetap menjalankan aktivitas normal, tapi ditambah dengan penerapan protokol kesehatan guna mencegah terjadinya penularan Covid-19. Setelah pemberlakuan new normal otomatis bedampak terhadap aktivitas-aktivitas rutin yang dilakukan setiap hari oleh masyarakat khususnya aktivitas yang pada saat New normal dilakukan pembatasan oleh pemerintah. Penelitian ini bertujuan menganalisis perbandingan persepsi dan perilaku adaptasi antara karyawan dan wirausahwan saat penerapan New normal pada masa pandemi Covid-19. Pendekatan yang digunakan yaitu menggunakan pendekatan Theory of Planned Behavior (TPB) yang dimodifikasi. Sebanyak 427 responden yang sudah bekerja telah menjawab kuesioner online yang berisi 61 pertanyaan. Pada penelitian ini, setelah dilakukan klasifikasi karakteristik responden dilanjutkan analisis deskriptif dengan pendekatan standar deviasi dan nilai mean serta dilakukan uji independent sample T-test dengan menggunakan software SPSS 25. Hasil menujukkan tidak dapat perbedaan yang signifikan antara karyawan dan wirausahawan pada indikator berperilaku adaptasi serta niat berperilaku adaptasi, perbedaan tidak signifikan juga terdapat pada indikator kerentanan dan pemahaman akan covid-19. Perbedaan signifikan antara karyawan dan wirausahawan terdapat pada indikator sikap pada covid-19 yang mudah menyebar, jumlah kasus meninggal, pengaruh teman-teman, kemampuan memiliki kuota internet, perilaku kerja dimasa lalu, perilaku mencuci tangan dimasa lalu, keparahan yang dirasakan terkait biaya pengobatan jika terkena Covid-19 dan berkurangnya pendapatan akibat parahnya Covid-19. Persepsi antara karyawan dan wirausahawan memiliki perbedaan yang signifikan pada beberapa indikator. Perbedaan-perebdaaan tersebut timbul karena pengaruh lingkungan mereka, baik lingkungan kerja maupun lingkungan sekitar tempat tinggal mereka.
\end{abstract}

Kata kunci: Covid-19, adapted behavior, new normal, theory of planned behavior, employee, entrepreneur

\footnotetext{
${ }^{1}$ Corresponding author:

Email: m.azkakesuma.w@gmail.com
} 


\section{INTRODUCTION}

On December 31, 2019, an ophthalmologist had revealed a new type of virus in Wuhan, Hubai Province, China. The virus was later called SARS-CoV-2, which can cause severe acute breathing. (Chirico et al., 2020). After causing a pandemic, , it will impact the Indonesian people's economy, so that it is necessary to have the ability to maintain people's purchasing power because it affects the sustainability of the country's economy. For the sake of realizing a stable economy, the government responds with the application of new normal life, namely an understanding of being able to live side by side with the Covid- 19 pandemic so that national economic stability is maintained in the medium and long term (Ministry of Health of the Republic of Indonesia, 2020).

During the Covid-19 pandemic, which cause the community to spend more time at home, led to a significant changes in peoples' behaviourincluding communication behavior, shopping behavior, behavior in other social life, and restricted community activities (Yuswohady et al., 2020). Behavior changes that are influenced by the work environment and the community environment certainly make the views of employees and entrepreneurs differ on employees' work environment where they are bound by the regulations in their place of work related to the prevention of Covid-19 transmission. For example, after the Covid-19 pandemic, many companies/government agencies encouraged their employees to Work From Home (WFH) to minimize the virus's spread in the work environment. Unlike the case with entrepreneurs where they are the business owners, they can make their own rules whether they will WFH or not. The Covid-19 pandemic has also greatly affected people's economic activities, reported on the lipi.go.id webpage. In addition to the health sector, the Covid-19 pandemic has bought a great impact on the economic sector, especially job security and income. As many as $15.6 \%$ of workers experienced layoffs, and $40 \%$ of workers experienced a decrease in income, of which $7 \%$ of workers' income fell by $50 \%$. Moreover, in entrepreneurship, 39.4 percent of businesses stopped, and 57.1 percent of businesses experienced decreased production andonly 3.5 percent of them were not affected. This happened because several companies experienced a decline in production and even stopped producing. The government's new normal includes more short-term behavior changes as an emergency response to the COVID-19 outbreak. These behaviors are related to maintaining physical distancing, as well as wearing masks (HIMPSI, 2020). On research by Mulyani et al. (2020), internal factors such as personality can affect employees' quality of life during the COVID-19 pandemic, and too much work also affects the quality of life of employees, especially those who work in hospitals. Through research conducted by Hidayat et al. (2020), entrepreneurs found a positive relationship between crisis management supported by government support and entrepreneurs' personality during the Covid-19 pandemic.

This study uses the variables in the Theory of Planned Behavior (TPB) to group the indicators of the questions asked. To avoid a widespread focus resulting in errors in interpreting the research objectives, this study is limited to a descriptive study using descriptive statistics to see differences in perceptions between employees and entrepreneurs of all subsequent indicators of use. Based on these problems, this study aims to know the difference in perceptions between employees and entrepreneurs during the Covid-19 pandemic. This research was conducted on people who already have jobs as employees or entrepreneurs in areas exposed to COVID-19 with the red zone category due to the enforcement. New normal in the red zone. Besides, Bogor City and Regency's determination, which are categorized as red zones as the scope, is also expected to provide more accurate answers.

\section{METHOD}

This research was conducted for three months from September 2020 to November 2020 in the City and Regency of Bogor. Data were collected by conducting interviews using online questionnaires distributed through Whatsapp groups / personal chats, Facebook groups, and Instagram accounts. Primary data in this study were obtained through interviews using online questionnaires, while secondary data were obtained from literature and various relevant scientific journals.

The target respondents in this study already have jobs as employees and entrepreneurs with the population of the City and Regency of Bogor who have jobs / economic activities. The sample was selected using the non-probability sampling method through the purposive sampling method. Determination of the number of samples using the rules of Bentler and Chou (1987) where 1 question indicator is multiplied between 
5-10 so that multiplication of 6 is used multiplied by the number of question indicators and obtained 427 respondents consisting of 264 employees and 163 entrepreneurs.

The data obtained are processed and analyzed using descriptive analysis and the Independent Sample T-test using SPSS25 software to see whether there is a significant difference between the perceptions of employees and entrepreneurs. This study's measuring instrument is a Likert scale with a range of 1 (Strongly Disagree) to 5 (Strongly Agree). Descriptive statistical test or descriptive statistical analysis is very important in a study because descriptive statistics have a useful purpose of analyzing respondents' responses to each indicator item in the questionnaire. In this study, after classifying the respondents' characteristics, it was followed by a cross-tabulation test and then carried out a descriptive analysis using the standard deviation approach and the mean value.

The total mean value indicates that the closer to or even reaching the number 5 (the highest score on the Likert scale used), the respondent will increasingly reflect a positive/agreeable attitude towards these variables. As a reference for assessment, based on the average value per variable, then grouped into five categories as follows:

Very low / Strongly disagree: $1.00-1.80$

Low / Disagree: $1.81-2.60$

Medium / Neutral: 2.61 - 3.40

Height / Agree: 3.41 - 4.20

Very high / Strongly agree: $4.21-5.00$

The intervals in the above categories are obtained from the following calculations:

$$
\begin{aligned}
\text { Interval }= & \underset{\text { Nilai Maksimal-Nilai Minimal }) /(\text { Jumlah }}{ } \\
& \text { Ketagori }) \\
= & (5-1) / 5=0,8
\end{aligned}
$$

Standard deviation represents the diversity of data from an indicator. When the standard deviation is greater than the mean, the indicator's diversity will vary. The total mean value indicates that the closer to or even reaching the number 5 (the highest score on the Likert scale used), the respondent will increasingly reflect a positive/agreeable attitude towards these variables.
Independent Sample T-Test was conducted to determine whether there was a significant difference in the mean or mean between the two independent groups on the interval/ratio data scale. The two independent groups referred to here are two unpaired groups, meaning that the data sources come from different subjects. The basis for determining the Independent T-test is based on a significance value (2-tailed) which measures the presence or absence of average differences in the tested subjects: a) The significance value (2-tailed) $>0.05$ indicates no significant average difference between study subjects; b) The significance value (2-tailed) $\leq$ 0.05 indicates a significant mean difference between study subjects. For the sake of harmony in understanding the series of research stages, it is simplified in an operational framework (Figure 1).

\section{RESULTS}

\section{Characteristics of Respondents}

The survey in this study was conducted on 427 respondents using an online questionnaire. The respondents' characteristics in this study were grouped by sex, age, education, domicile, and workgroup. In Table 1, we can see the percentage of the characteristics of the respondents that the researcher has collected data.

\section{Descriptive Analysis and Independent Sample T-test}

Adaptive behavior

Adapted behavior reflects the behavior of employees and entrepreneurs during the Covid-19 pandemic. Adaptive behavior during the pandemic is reflected by complying with health protocols in the new normal during the Covid-19 pandemic. Based on Table 2, where the question indicator refers to research (Barati et al., 2020; KEMENKES RI, 2020; Lee et al., 2020; Oyeniran and Chia, 2020; Sen-Crowe, McKenney and Elkbuli, 2020; UNICEF, 2020) shows that statistically descriptive there is an average difference between the behavior of employees and entrepreneurs, but the difference is not significant (real) because the independent sample t-test results show the sig value (2-tailed) does not meet the requirements of significance $(\leq 0.05)$. 


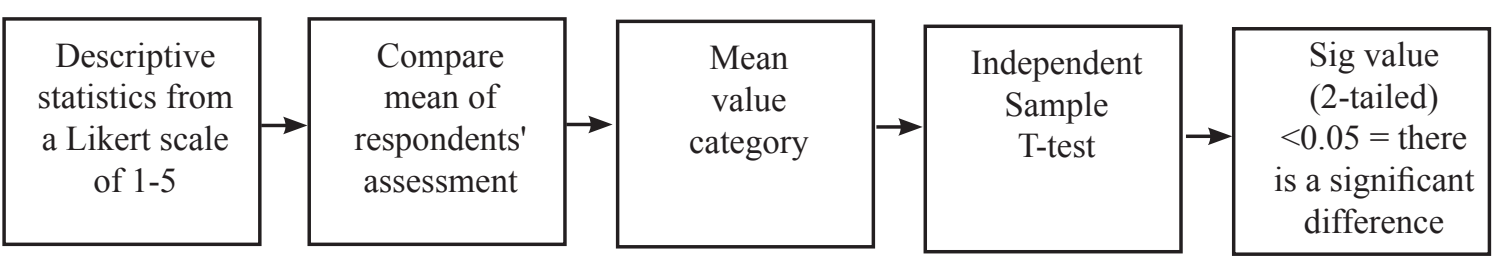

Figure 1. Research framework

Table 1. Characteristics of respondents

\begin{tabular}{llc}
\hline Characteristics & Classification & Number of respondents \\
\hline Gender & Man & 188 \\
& Women & 239 \\
Age & $\leq 20$ years & 81 \\
& $21-30$ years & 188 \\
& $31-40$ years & 60 \\
& $41-50$ Years & 77 \\
& $>50$ Years & 21 \\
\hline
\end{tabular}

\begin{tabular}{llc}
\hline Characteristics & Classification & Number of respondents \\
\hline Last education & SMA / SMK & 137 \\
& S1 & 265 \\
& S2 / S3 & 26 \\
Domicile & Bogor city & 205 \\
& Bogor Regency & 222 \\
Job & Employees & 264 \\
& Entrepreneur & 163 \\
\hline
\end{tabular}

Table 2. Descriptive Analysis and T-Test of adaptation behavior of employees and entrepreneurs

\begin{tabular}{lccccc}
\hline \multirow{2}{*}{\multicolumn{1}{c}{ Indicator }} & \multicolumn{2}{c}{ Employees } & \multicolumn{2}{c}{ Entrepreneur } & \multirow{2}{*}{ Sig (2-Tailed) } \\
\cline { 2 - 5 } & Mean & Std. Deviation & Mean & Std. Deviation & \\
\hline AB1: Washing hands & 4.78 & 0.61 & 4.82 & 0.52 & 0.857 \\
AB2: Put on a mask & 4.79 & 0.6 & 4.87 & 0.49 & 0.925 \\
AB3: Keep the distance & 3.75 & 1.14 & 3.71 & 1.09 & 0.343 \\
AB4: Working at home & 3.7 & 1.11 & 3.7 & 1.06 & 1,000 \\
AB5: Worship at home & 3.8 & 1.05 & 3.84 & 1.1 & 0.961 \\
AB6: Reduce shopping activities & 3.92 & 0.99 & 3.96 & 1.02 & 0.458 \\
AB7: Using a private vehicle & 3.31 & 1.21 & 3.33 & 1.09 & 1,000 \\
AB8: Not on vacation & 3.28 & 1.15 & 3.33 & 1.05 & 0819 \\
AB9: Adopt a healthy lifestyle & 3.79 & 1.03 & 3.85 & 1.03 & 0.907 \\
AB10: Do not go to the crowd & 4.2 & 1.02 & 4.2 & 1.04 & 0.567 \\
\hline
\end{tabular}

The terms of significance $=\operatorname{Sig}(2$-tailed $) \leq 0.05$

Intention

The intention to behave in adapting to employees and entrepreneurs reflects their desire to behave in adaptive behavior during the Covid-19 pandemic by planning / intending to carry out health protocols. Following are the results of descriptive analysis and t-test related to the intention to behave in adaptation during the Covid-19 pandemic. Table 3 with indicators refers to research (Barati et al., 2020; KEMENKES RI, 2020; Lee et al., 2020; Oyeniran \& Chia, 2020; Sen-Crowe et al., 2020; UNICEF, 2020) shows that descriptively statistically, there is a difference in the average intention of adaptation behavior between employees and entrepreneurs, but this difference is not significant (real) because the results of the independent sample t-test show the sig value (2-tailed) does not meet the significance requirements $(\leq 0.05)$
Attitude

The community's attitude towards the Covid-19 pandemic can be built by an understanding of the situation, an understanding of the impact and an understanding of opportunities. Following are the results of descriptive analysis and t-test related to the community's attitudes during the Covid-19 pandemic. From Table 4 with indicators refers to research (D'Amours, 2020; Dariya and Nagaraju, 2020; Roy et al., 2020; Sarkodie and Owusu, 2020; Shader, 2020), it can be seen that statistically descriptive there is a difference in the average between employee and entrepreneurial behavior, the A2 indicator: it is easy and fast to get infected with the Sig value (2-tailed) shows $0.034 \leq 0.05$ and the A6 indicator: The number of cases died is greater, which shows the sig value (2-tailed) of $0.037 \leq 0.05$, this explains that there is a significant 
difference between the attitudes of employees and the attitudes of entrepreneurs regarding the Covid19 pandemic which is easily and quickly transmitted. what can form this attitude from various factors such as the work environment, the people around them, their understanding and others. However, this difference is not significant (real) on other indicators because the results of the independent sample t-test show that the sig value (2-tailed) does not meet the significance requirements $(\leq 0.05)$.

\section{Subjective Norms}

Society in making decisions can be influenced by the opinions of other people or the surrounding environment. Following are the results of descriptive analysis and t-test related to subjective norms during the Covid-19 pandemic to see people's influence and their surroundings in making decisions. From Table 5 with indicators refers to research (Prasetyo et al., 2020; Rubio-Romero et al., 2020; Yancey-Bragg \& Bravo, 2020), it can be seen that statistically descriptively, there is an average difference between employees' and entrepreneurs' behavior. On the SN3 indicator: Friends, the Sig value (2-tailed) shows $0.019 \leq 0.05$. The explains that there is a significant difference between employee's subjective norms. Furthermore, the entrepreneur's subjective norms related to the influence of friends on the Covid-19 pandemic. Friends in the environment around employees and entrepreneurs give them different influences. Friends in the work environment can be one of the factors that give them influence in responding to the Covid-19 pandemic. However, this difference is not significant (real) on other indicators because the results of the independent sample t-test show that the sig value (2-tailed) does not meet the significance requirements $(\leq 0.05)$.

Table 3. Descriptive Analysis and T-Test of behavioral adaptation intentions of employees and entrepreneurs

\begin{tabular}{|c|c|c|c|c|c|}
\hline \multirow{2}{*}{ Indicator } & \multicolumn{2}{|c|}{ Employees } & \multicolumn{2}{|c|}{ Entrepreneur } & \multirow{2}{*}{ Sig (2-Tailed) } \\
\hline & Mean & Std. Deviation & Mean & Std. Deviation & \\
\hline I1: Washing hands & 4.21 & 0.89 & 4.15 & 1.04 & 0.493 \\
\hline I2: Put on a mask & 4.00 & 0.88 & 4.04 & 0.99 & 0.720 \\
\hline I3: Keep the distance & 4.21 & 0.89 & 4.13 & 1.04 & 0.439 \\
\hline I4: Working at home & 4.76 & 0.60 & 4.77 & 0.63 & 0849 \\
\hline I5: Worship at home & 4.78 & 0.57 & 4.83 & 0.53 & 0.423 \\
\hline I6: Reducing shopping activities & 4.52 & 0.73 & 4.62 & 0.70 & 0.146 \\
\hline I7: Using a private vehicle & 3.97 & 1.00 & 3.96 & 1.12 & 0.979 \\
\hline I8: Not on vacation & 4.52 & 0.73 & 4.62 & 0.70 & 0.146 \\
\hline I9: Adopting a healthy lifestyle & 4.21 & 0.89 & 4.15 & 1.04 & 0.493 \\
\hline
\end{tabular}

The terms of significance $=\operatorname{Sig}(2$-tailed $) \leq 0.05$

Table 4. Descriptive Analysis and T-Test Adaptation attitudes of employees and entrepreneurs

\begin{tabular}{|c|c|c|c|c|c|}
\hline \multirow{2}{*}{ Indicator } & \multicolumn{2}{|c|}{ Employees } & \multicolumn{2}{|c|}{ Entrepreneur } & \multirow{2}{*}{ Sig (2-Tailed) } \\
\hline & Mean & Std. Deviation & Mean & Std. Deviation & \\
\hline A1: A dangerous disease & 3.95 & 1.01 & 4.02 & 1.14 & 0.521 \\
\hline A2: It is easy and contagious & 3.81 & 1.02 & 3.90 & 0.97 & $0.034 *$ \\
\hline A3: A vaccine has not been found & 3.94 & 1.02 & 4.01 & 1.11 & 0.550 \\
\hline A4: Limited health facilities & 3.92 & 1.02 & 3.99 & 1.16 & 0.494 \\
\hline A5: Limited health personnel & 3.76 & 1.02 & 3.89 & 0.98 & 0.201 \\
\hline A6: The number of cases died is greater & 3.84 & 1.02 & 3.93 & 0.96 & $0.037 *$ \\
\hline A7: Medical personnel become victims & 3.83 & 0.85 & 3.87 & 0.90 & 0.649 \\
\hline A8: Health is more important & 3.93 & 1.01 & 4.00 & 1.12 & 0.518 \\
\hline I9: Adopting a healthy lifestyle & 4.21 & 0.89 & 4.15 & 1.04 & 0.493 \\
\hline
\end{tabular}

The terms of significance $=\operatorname{Sig}(2$-tailed $) \leq 0.05$ 
Table 5. Descriptive Analysis and Subjective Norm-T-test for employees and entrepreneurs

\begin{tabular}{lccccc}
\hline \multirow{2}{*}{ Indicator } & \multicolumn{2}{c}{ Employees } & \multicolumn{2}{c}{ Entrepreneur } & \multirow{2}{*}{ Sig (2-Tailed) } \\
\cline { 2 - 5 } & Mean & Std. Deviation & Mean & Std. Deviation & \\
\hline SN1: Family & 3.98 & 0.96 & 4.06 & 0.91 & 0.415 \\
SN2: Television & 3.89 & 0.82 & 3.98 & 0.83 & 0.278 \\
SN3: Guys & 4.09 & 0.88 & 4.20 & 0.83 & $0.019 *$ \\
SN4: Social media & 3.96 & 1.03 & 4.07 & 0.92 & 0.269 \\
SN5: Clerics and religious figures & 4.26 & 0.83 & 4.29 & 0.87 & 0.215 \\
\hline
\end{tabular}

The terms of significance $=\operatorname{Sig}(2$-tailed $) \leq 0.05$

Perceived behavioral control

The following are the descriptive analysis and t-test related to employees' and entrepreneurs' behavior control during the Covid-19 pandemic. Community behavior control is based on the abilities they have in dealing with choices in behavior. From Table 6 with indicators refers to research (Sato, 2018; Barati et al., 2020; Shen et al., 2020), it can be seen that statistically descriptively, there is a difference in average between employee and entrepreneurial behavior, on the PBC5 indicator: having an internet quota, the Sig value (2-tailed) shows $0.047 \leq 0.05$ this explains that there is a significant difference between employee and attitudes of entrepreneurs regarding the ability to have internet quotas during the Covid-19 pandemic. Some workplaces provide internet quotas to their employees aimed at supporting their work productivity. Entrepreneurs who have their businesses do not have an obligation to do the same. However, this difference is not significant (real) on other indicators because the results of the independent sample t-test show that the sig value (2-tailed) does not meet the significance requirements $(\leq 0.05)$.

\section{Past behavior}

Past behavior can be used as a basis or capital in making decisions to behave in the future, past behavior as an experience that has been felt can influence a person to decide. Following are the results of descriptive analysis and t-test related to past behavior during the Covid19 pandemic. From Table 7 with indicators refers to research (Barati et al., 2020; KEMENKES RI, 2020; Lee et al., 2020; Oyeniran \& Chia, 2020; Sen-Crowe et al., 2020; UNICEF, 2020), it can be seen that statistically descriptive there is an average difference between the behavior of employees and entrepreneurs, on the PB1 indicator: working at home has a sig (2-tailed) value of $0.047 \leq 0.05$ and PB6: Washing hands, the Sig (2-tailed) value indicates $0.049 \leq 0.05$, this explains that there is a significant difference between the assessment of employees and entrepreneurs regarding working and washing hands in the past. Employees do not have the authority regarding their work behavior, in contrast to entrepreneurs who have power over their work behavior whether they work from home or work from an office/business place. However, this difference is not significant (real) on other indicators because the results of the independent sample t-test show that the sig value (2-tailed) does not meet the significance requirements $(\leq 0.05)$.

\section{Perceptions of vulnerability}

Covid-19, which has become a pandemic/epidemic globally, makes people think they are also vulnerable to contracting it. Perceptions of vulnerability that they might feel can be an influence on behavior during the Covid-19 pandemic. Following are the results of descriptive analysis and t-test related to the vulnerability that might be felt during the Covid-19 pandemic. From Table 8 with indicators refers to research (Díaz, Soriano and Beleña, 2016; Coccia, 2020; González-Olmo et al., 2020; Guerin and Toland, 2020; Nicola et al., 2020), it can be seen that statistically descriptively, there is a difference in average between the perceptions of employees and entrepreneurs regarding vulnerability to Covid-19, but this difference is not significant (real) because the results of the independent sample t-test show a sig (2-tailed) value. ) does not meet the significance requirements $(\leq 0.05)$. 
Table 6. Descriptive Analysis and T-Test Perceptions of controlling the behavior of employees and entrepreneurs

\begin{tabular}{lccccc}
\hline \multirow{2}{*}{\multicolumn{1}{c}{ Indicator }} & \multicolumn{2}{c}{ Employees } & \multicolumn{2}{c}{ Entrepreneur } & \multirow{2}{*}{ Sig (2-Tailed) } \\
\cline { 2 - 5 } & Mean & Std. Deviation & Mean & Std. Deviation & \\
\hline PBC1: Have patience & 3.47 & 1.05 & 3.47 & 1.05 & 0.979 \\
PBC2: Have savings & 3.51 & 1.15 & 3.48 & 1.25 & 0.807 \\
PBC3: Have a steady income & 3.81 & 1.02 & 3.75 & 1.10 & 0.553 \\
PBC4: Have entertainment & 3.53 & 1.09 & 3.55 & 1.18 & 0.216 \\
PBC5: Has internet quota & 3.47 & 1.06 & 3.67 & 1.18 & $0.047 *$ \\
PBC6: Have a supply of food & 3.53 & 1.16 & 3.48 & 1.25 & 0.725 \\
\hline
\end{tabular}

The terms of significance $=\operatorname{Sig}(2$-tailed $) \leq 0.05$

Table 7. Descriptive Analysis and T-Test Past behavior of employees and entrepreneurs

\begin{tabular}{lccccc}
\hline \multirow{2}{*}{\multicolumn{1}{c}{ Indicator }} & \multicolumn{2}{c}{ Employees } & \multicolumn{2}{c}{ Entrepreneur } & Sig \\
\cline { 2 - 5 } & Mean & Std. Deviation & Mean & Std. Deviation & (2-Tailed) \\
\hline PB1: Working at home & 3.84 & 1.05 & 3.77 & 1.18 & $0.047^{*}$ \\
PB2: Worship at home & 4.12 & 0.96 & 4.13 & 1.02 & 0.857 \\
PB3: Reducing shopping activities & 4.19 & 0.83 & 4.21 & 0.86 & 0.784 \\
PB4: Reducing social activities outside the home & 4.68 & 0.67 & 4.74 & 0.64 & 0.377 \\
PB5: Put on a mask & 4.54 & 0.79 & 4.60 & 0.67 & 0.473 \\
PB6: Washing hands & 4.41 & 0.71 & 4.55 & 0.67 & $0.049 *$ \\
PB7: Keep the distance & 4.22 & 0.98 & 4.23 & 0.96 & 0.859 \\
PB8: Using a private vehicle & 4.13 & 1.03 & 4.07 & 1.10 & 0.585 \\
PB9: No vacation & 3.84 & 1.05 & 3.77 & 1.18 & $0.047 *$ \\
\hline
\end{tabular}

The terms of significance $=\operatorname{Sig}(2$-tailed $) \leq 0.05$

Table 8. Descriptive Analysis and T-Test Perceptions of the vulnerability of employees and entrepreneurs

\begin{tabular}{lccccc}
\hline \multirow{2}{*}{ Indicator } & \multicolumn{2}{c}{ Employees } & \multicolumn{2}{c}{ Entrepreneur } & Sig \\
\cline { 2 - 5 } & Mean & Std. Deviation & Mean & Std. Deviation & (2-Tailed) \\
\hline PV1: Very vulnerable & 3.28 & 1.08 & 3.46 & 1.12 & 0.498 \\
PV2: Environment is very vulnerable & 3.46 & 1.15 & 3.52 & 1.13 & 0.602 \\
PV3: It is easy to get infected if people around & 3.57 & 1.01 & 3.74 & 1.03 & 0.769 \\
are infected & & & & & \\
PV4 Susceptible to disease & 3.07 & 1.04 & 2.93 & 1.03 & 0.286 \\
PV5: Possible family infection & 3.46 & 1.15 & 3.53 & 1.13 & 0.101 \\
\hline
\end{tabular}

The terms of significance $=\operatorname{Sig}(2$-tailed $) \leq 0.05$

\section{Perception of Severity}

Besides, the impact of a disease pandemic can shape perceptions of the perceived severity and severity of an illness, making a person more aware of the decisions they make to behave. Following are the results of descriptive analysis and t-test regarding the severity felt during the Covid-19 pandemic. From Table 9 with indicators refers to research (Shah et al., 2010; Barati et al., 2020; Cássaro and Pires, 2020; Paital, Das and Parida, 2020), it can be seen that statistically descriptively, there is an average difference between employee and entrepreneur perceptions of the severity of the Covid-19 pandemic, on the PS2 indicator: expensive treatment, the Sig (2-tailed) value shows $0.045 \leq 0.05$ and the PS5 indicator: Income reduced shows a Sig (2-tailed) value of $0.043 \leq 0.05$, this explains that there is a significant difference between the perceptions of employees and entrepreneurs regarding the severity of Covid-19 during the Covid-19 pandemic. Employees who have monthly salaries have different perceptions with entrepreneurs that come from their sales results, many entrepreneurs have closed their businesses during the Covid-19 pandemic because of the absence/decline in sales, this has an impact on their income and their ability to meet their daily needs. 
Knowledge

A person's understanding of the situation during a pandemic can certainly change their attitude to behave according to their understanding. Following are the results of descriptive analysis and t-test related to understanding the Covid-19 pandemic. From Table 10 with indicators refers to research (Coccia, 2020; Liu, 2020; Nicola et al., 2020; Shim \& Chowell, 2020) above, it can be seen that statistically descriptive there is a difference in the average between employee and entrepreneurial behavior, but this difference is not significant (real) because the results of the independent sample t-test show that the sig (2-tailed) value does not meet the significance requirements $\leq 0.05$ ).

\section{Managerial Implications}

Based on the results of the research above where several indicators still have a mean value in the moderate/neutral category, such as not going on vacation, using private vehicles, perceptions of being very vulnerable to being exposed to Covid-19 and being easily exposed to Covid19 which reflects that employees and entrepreneurs have not performed yet this behavior well so that there is still a massive spread of Covid-19. Managerial implications can be taken from this research by conducting effective socialization of these indicators by policymakers. In particular, understanding the vulnerability and severity of Covid-19 is still considered trivial by many people.

\section{CONCLUSIONS AND RECOMMENDATIONS}

\section{Conclusions}

Adaptation behavior between employees and entrepreneurs does not have a significant (real) difference. In practice, both employees and entrepreneurs show adaptive behavior according to health protocols indicated by the majority mean value $>$ 4. The intention to behave in adaptation, employees and entrepreneurs also do not have a significant difference but already have the intention to behave accordingly. It can be concluded that employee's and entrepreneurs' adaptive behavior is following the planned intentions. The attitudes of employees and entrepreneurs have significant differences in easy and quickly transmitted attitudes and the number of cases of death. Employees and entrepreneurs also have significant differences regarding the influence of their friends on the Covid19 pandemic. The views between employees and entrepreneurs are also different regarding the ability to have internet quotas. Past behavior of employees and entrepreneurs is significantly different in indicators of working from home and washing hands. Perceptions of vulnerability between employees and entrepreneurs do not have a significant difference in all indicators, and a significant difference is in the indicators of perceived severity of perceived medical costs and reduced income. The understanding between employees and entrepreneurs also does not have a significant difference. Workplace, friends, abilities between employees and entrepreneurs are factors that influence them in shaping their perceptions. The work environment of employees who already have their regulations has a great influence on employee perceptions, while entrepreneurs who own their businesses do not have the same situation because entrepreneurs have their authority regarding their work environment.

\section{Recommendations}

The limitation of this study is the focus of the adaptation behavior under study. Further research can be carried out focusing on work behavior and its impact on the work performed. Behavior comparison on work more vulnerable to covid-19 as health personnel can more reflect the effect of the covid-19 pandemic.

Table 9. Descriptive Analysis and Perceptions of Severity T-Test for employees and entrepreneurs

\begin{tabular}{lccccc}
\hline \multirow{2}{*}{\multicolumn{1}{c}{ Indicator }} & \multicolumn{2}{c}{ Employees } & \multicolumn{2}{c}{ Entrepreneur } & \multicolumn{2}{c}{ Sig } \\
\cline { 2 - 4 } & Mean & Std. Deviation & Mean & Std. Deviation & (2-Tailed) \\
\hline PS1: Affects mental health & 3.66 & 1.03 & 3.74 & 1.08 & 0.617 \\
PS2: Expensive treatment & 3.84 & 1.02 & 3.93 & 1.00 & $0.045 *$ \\
PS3: The certainty will end & 3.99 & 0.99 & 4.07 & 0.98 & 0.170 \\
PS4: My country is worse than other countries & 3.51 & 1.13 & 3.45 & 1.12 & 0.544 \\
PS5: Income decreases & 3.50 & 1.13 & 3.64 & 1.16 & $0.043 *$ \\
\hline
\end{tabular}

The terms of significance $=\operatorname{Sig}(2$-tailed $) \leq 0.05$ 
Table 10. Descriptive Analysis and T-Test Understanding of employees and entrepreneurs

\begin{tabular}{lcccccc}
\hline & \multirow{2}{*}{ Indicator } & \multicolumn{2}{c}{ Employees } & \multicolumn{2}{c}{ Entrepreneur } & \multicolumn{2}{c}{ Sig } \\
\cline { 2 - 5 } & Mean & Std. Deviation & Mean & Std. Deviation & (2-Tailed) \\
\hline K1 & 4.45 & 0.69 & 4.40 & 0.75 & 0.417 \\
K2 & 4.27 & 0.80 & 4.31 & 0.80 & 0.409 \\
K3 & 4.33 & 0.70 & 4.31 & 0.70 & 0.632 \\
K4 & 4.27 & 0.88 & 4.36 & 0.81 & 0.325 \\
\hline
\end{tabular}

The terms of significance $=\operatorname{Sig}(2$-tailed $) \leq 0.05$

\section{REFERENCES}

Barati M. et al. 2020. Factors associated with preventive behaviours of COVID-19 among hospital staff in Iran in 2020: an application of the Protection Motivation Theory. Journal of Hospital Infection 105(3): 430-433. https://doi.org/10.1016/j. jhin.2020.04.035.

Cássaro FAM, Pires LF. 2020. Can we predict the occurrence of COVID-19 cases? Considerations using a simple model of growth. Science of the Total Environment 728. https://doi.org/10.1016/j. scitotenv.2020.138834.

Chirico A. et al. 2020. COVID-19 Outbreak and Physical Activity in the Italian Population: A Cross-Sectional Analysis of the Underlying Psychosocial Mechanisms. Frontiers in Psychology, 11(August):1-13. https://doi. org/10.3389/fpsyg.2020.02100.

Coccia M. 2020. Factors determining the diffusion of COVID-19 and suggested strategy to prevent future accelerated viral infectivity similar to COVID. Science of the Total Environment 729. https://doi.org/10.1016/j.scitotenv.2020.138474.

D'Amours K. 2020. Stop the spread of COVID-19 by wearing your face mask properly', WWLP.Com, 3 April. Available at: https://www.wwlp.com/ news/health/coronavirus-local-impact/combatcovid-19-spread-by-wearing-your-face-maskproperly/. [22 Sept 2020].

Dariya B, Nagaraju GP. 2020. Understanding novel COVID-19: Its impact on organ failure and risk assessment for diabetic and cancer patients. Cytokine and Growth Factor Reviews, pp. 43-52. dhttps://doi.org/10.1016/j.cytogfr.2020.05.001.

Díaz A, Soriano JF, Beleña Á. 2016. Perceived Vulnerability to Disease Questionnaire: Factor structure, psychometric properties and gender differences. Personality and Individual Differences 101:42-49.https://doi.org/10.1016/j. paid.2016.05.036.
González-Olmo MJ. et al. 2020. Perceived vulnerability to Coronavirus infection: Impact on dental practice. Brazilian Oral Research 34. https://doi. org/10.1590/1807-3107bor-2020.vol34.0044.

Guerin RJ, Toland MD. 2020. An application of a modified theory of planned behavior model to investigate adolescents' job safety knowledge, norms, attitude and intention to enact workplace safety and health skills. Journal of Safety Research 72(December): 189-198. https://doi. org/10.1016/j.jsr.2019.12.002.

Hidayat M. et al. 2020. Factors Influencing Resilience of Micro Small and Medium Entrepreneur (MSME) during COVID 19 Outbreak in South Sulawesi Province Indonesia. TEST Engineering \& Management 83(26): 707-26721. https://doi. org/10.31219/osf.io/cme2j.

HIMPSI. 2020. Perubahan Perilaku Sebagai Respon Terhadap Wabah, Himpunan PsikologiIndonesia . https://himpsi.or.id/blog/materi-edukasi-covid19-5/post/perubahan-perilaku-sebagai-responterhadap-wabah-covid-19-130 [25 Sept 2020].

KEMENKES RI. 2020. Adaptasi Kebiasaan Baru, 06 Maret 2020. Kemenkes.go.id [22 Sept 2020].

Mulyani I. et al. 2020. Factors influencing employee's quality of life during COVID-19 pandemic. Indigenous: Jurnal Ilmiah Psikologi 5(2):164174. https://doi.org/10.23917/indigenous. v5i2.11086.

Nicola M. et al. 2020. Evidence based management guideline for the COVID-19 pandemic - Review article. International Journal of Surgery 77: 206216. https://doi.org/10.1016/j.ijsu.2020.04.001.

Paital B, Das K, Parida SK. 2020. Inter nation social lockdown versus medical care against COVID-19, a mild environmental insight with special reference to India. Science of the Total Environment 728:138914. https://doi. org/10.1016/j.scitotenv.2020.138914.

Roy D. et al. 2020. Study of knowledge, attitude, anxiety \& perceived mental healthcare need in 
Indian population during COVID-19 pandemic. Asian Journal of Psychiatry 51. https://doi. org/10.1016/j.ajp.2020.102083.

Sarkodie SA, Owusu PA. 2020. Investigating the cases of novel coronavirus disease (COVID-19) in China using dynamic statistical techniques. Heliyon 6(4).https://doi.org/10.1016/j.heliyon.2020. e03747.

Sato APS. 2018. What is the importance of vaccine hesitancy in the drop of vaccination coverage in Brazil?. Revista de Saude Publica 52(2018):1-9. https://doi.org/10.11606/S15188787.2018052001199.

Shader RI. 2020. COVID-19 and Depression. Clinical Therapeutics 42(6): 962-963. https://doi. org/10.1016/j.clinthera.2020.04.010.

Shah M. et al. 2010. Perceived stress, sources and severity of stress among medical undergraduates in a Pakistani medical school. BMC Medical Education 10(1). https://doi.org/ 10.1186/14726920-10-2.

Shen K. et al. 2020. Diagnosis, treatment, and prevention of 2019 novel coronavirus infection in children: experts' consensus statement. World Journal of Pediatrics. 223-231. https://doi.org/10.1007/ s12519-020-00343-7.

Yuswohady et al. 2020. Consumer behaviour new normal after COVID-19. Inventure Knowledgen1-40. 